\title{
Use and conservation of Cracidae (Aves: Galliformes) in the Peruvian Amazon
}

\author{
Alfredo J. Begazo and Richard E. Bodmer
}

Four species of the avian family Cracidae were studied in the Pacaya-Samiria National Reserve in north-eastern Peru. These large-bodied birds are an important source of protein for local communities on the periphery of the reserve. An estimated $425 \mathrm{~kg}$ of Cracidae biomass were harvested over a 1-year period by three communities. Pipile cumanensis was the most frequently hunted bird, both in terms of individuals hunted and biomass extracted. Mitu tuberosa and Penelope jaquacu also made up a substantial amount of the biomass extracted, but were hunted less frequently. Densities of all species of Cracidae within $5 \mathrm{~km}$ of the villages were substantially lower than in the interior of the reserve. Our results suggest that $\mathrm{M}$. tuberosa and $\mathrm{P}$. cumanensis are overharvested and $\mathrm{P}$. jaquacu and Ortalis guttata are harvested within the maximum estimated sustainable levels. In this study hunting grounds were along waterways and adjacent to protected populations, which created a source-sink arrangement. If sink areas are overhunted, the unhunted populations inland of the waterways could be acting as source populations that replenish overhunted areas.

\section{Introduction}

Members of the Cracidae constitute a substantial part of the avian biomass in Neotropical bird communities (Terborgh, 1986). Cracids are an important element for maintaining plant communities, because they often defecate intact seeds (Erard and Sabatier, 1994; A.J.B., unpublished data) and move widely while foraging (Terborgh, 1986). Cracids are also important for rural people in the Neotropics (Terborgh, 1986; Vickers, 1991; Begazo, 1996). Studies on subsistence hunting show that cracids contribute substantial amounts of meat for rural people (Ayres et al., 1991; Vickers, 1991).

In many areas of Latin America cracid populations are declining. Subsistence hunting is an important cause of these declines (Delacour and Amadon, 1973; Thiollay, 1989; Ayres et al., 1991; Silva and Strahl, 1991; Strahl and Grajal, 1991; Vickers, 1991; Collar et al., 1992). Habitat destruction has also been responsible for population declines of several species (Strahl and Grajal, 1991) and for the near extinction of one curassow (Texeira and Snow, 1982).

Several studies have concluded that cracids are not suitable for wild-meat harvests because of their slow rate of population recovery (Lovejoy and Brash, 1984; Terborgh, 1986; Estudillo-Lopez, 1988; Silva and Strahl, 1991; Strahl and Grajal, 1991). Thus, conservation of cracids has focused only on fully protected areas (Estudillo-Lopez, 1988; Strahl and Grajal, 1991). Many cracid populations, however, inhabit areas outside parks and are hunted by rural people to varying degrees.

In this paper we use data on intensity of hunting and status of standing populations of four species of Cracidae - razor-billed curassow Mitu tuberosa, Spix's guan Penelope jaquacu, common piping-guan Pipile cumanensis and speckled chachalaca Ortalis guttata - to assess sustainability of harvesting wild populations of cracids in the Peruvian Amazon. We examine subsistence hunting activities of people in three rural communities. 


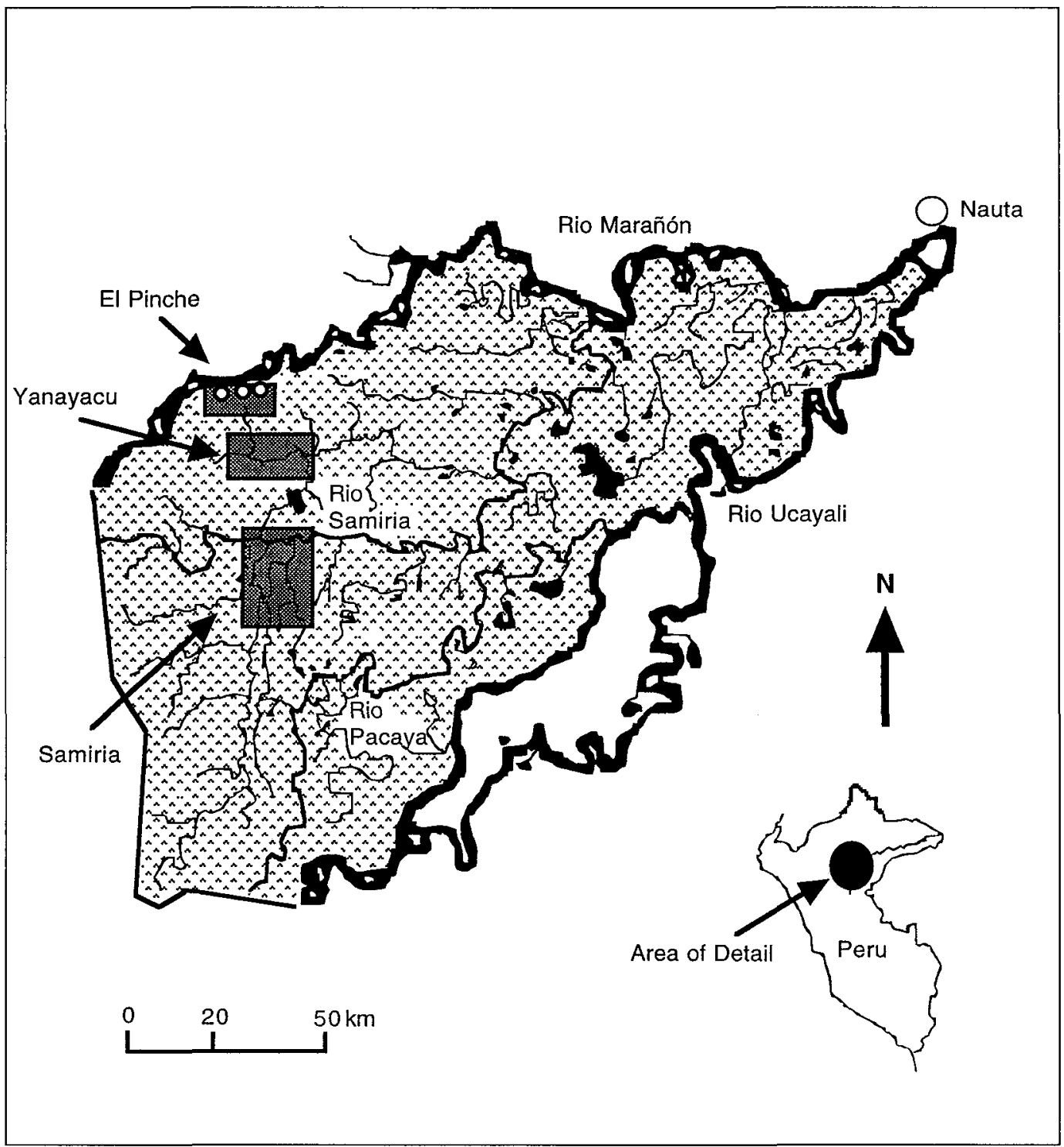

Figure 1. Map of the Pacaya-Samiria National Reserve showing the persistently hunted study site of El Pinche, the moderately hunted site of Yanayacu, and the lightly/non-hunted site of Samiria.

\section{Methods}

The study was conducted in three sites. The first site was located in the vicinity of the communities of Nueva Esperanza, Maipuco and San Antonio. These rural settlements are located along the Marañon River in the buffer zone of the Pacaya-Samiria National Reserve
(PSNR) in north-eastern Peru. People residing in these villages use the reserve to extract natural resources, despite these activities being prohibited.

The other two sites are within the PSNR at different distances from human settlements (Figure 1). The habitats at all study sites are dominated by várzea forest (seasonally (C) $1998 \mathrm{FFI}$, Oryx, 32 (4), 301-309 
flooded) and floodplain levees (high forest). The study was conducted between May 1995 and August 1996.

\section{Breeding biology}

Data on the breeding biology of cracids were collected from interviews with hunters and from published records on the reproductive biology of these species in captivity. Hunters were asked the following questions: (i) How many nests of each species of cracid have you found while living in the region, (ii) how many eggs did you see in each nest, (iii) which month of the year were the nests found, (iv) which month of the year do you see adult birds with fledglings, and (v) which month of the year are cracids most active vocally? Clutch size of each species was estimated as the average number of eggs found in nests reported by hunters.

\section{Habitat preferences}

Hunters were asked to rank the four species of cracids by their likelihood of being found in: (i) forest prone to inundation, (ii) floodplain levees or (iii) other types of forest. These data provided patterns of cracid biology from hunters who have many years' experience in the region. The results were analysed using the G2 (Likelihood-ratio) test.

\section{Population density estimates}

Densities of cracids were estimated in this study. These estimates were obtained from censuses carried out in the heavily hunted site of El Pinche (within $5 \mathrm{~km}$ of the villages), the moderately hunted site of Yanayacu (within $20 \mathrm{~km}$ of the villages) and the lightly/nonhunted site of Samiria, all within the PacayaSamiria National Reserve. The intensity of hunting in the three sites was deduced from interviews with hunters and reserve guards. Transects were surveyed in the mornings between 07.00 and $12.00 \mathrm{~h}$. We recorded the perpendicular distances between the bird and the trail (Buckland et al., 1993) and used the program DISTANCE (Laake et al., 1994) to estimate population densities. All transects were done on trails cut especially for density surveys. Transects in the heavily hunted site totalled $380 \mathrm{~km}$ surveyed on five $5-\mathrm{km}$-long trails. Transects in the moderately hunted site totalled $87 \mathrm{~km}$ and used trails and water courses. Transects in the lightly/non-hunted site totalled $402 \mathrm{~km}$ censused in 10 trails of 4 and $5 \mathrm{~km}$ long. Perpendicular distance was taken from the edge of the water to the location of the animal on censuses along water courses. A measure of $1 \mathrm{~m}$ was assigned for birds flying across water course transects (Silva and Strahl, 1991).

\section{Hunting}

The number of cracids harvested came from records of hunted animals kept by hunters, and from interviews. Hunters either kept a portion of the total number of birds they hunted as part of an ongoing participatory wildlife programme, or they reported hunting orally. Hunting activities were determined by direct observation at the villages and at hunting grounds 5 and $20 \mathrm{~km}$ from the villages. One of the authors A.J.B. spent 3 months in the villages (11 May-14 August 1995) and, because hunting pressure does not vary through the year, was able to obtain an estimate of the annual harvests. Mammalian game biomass consumed in the three villages was compared with the cracid data, and was obtained from a 1-year-long study at the same villages (Bodmer et al., in press).

\section{Sustainability of cracid hunting}

The production model of Robinson and Redford (1991) was used to evaluate whether cracids were overharvested. Production was calculated as:

$$
P_{\max }=\left[0.6 \mathrm{D} \times \mathrm{L}_{\max }\right]-0.6 \mathrm{D}
$$

where maximum production is assumed to occur when the population density is at 60 per cent of carrying capacity, $\mathrm{D}=$ density at carrying capacity (individuals/sq $\mathrm{km}$ ), and $\mathrm{L}_{\max }=$ the maximum finite rate of population increase from time $T_{0}$ to $T_{+1}$. Densities at carrying capacity were estimated from the lightly/ 
Table 1. Reproductive parameters used to estimate $\mathrm{L}_{\max }$ for cracid species in the Pacaya-Samiria National Reserve in a study carried out between May 1995 and August 1996

\begin{tabular}{lllllll}
\hline Species & $\begin{array}{l}\text { Body } \\
\text { mass } \\
(\mathrm{kg})\end{array}$ & $\begin{array}{l}\text { Age of first } \\
\text { breeding } \\
\text { (years) }(\mathrm{a})\end{array}$ & $\begin{array}{l}\text { No. female } \\
\text { young } \\
\text { (young/year) (b) }\end{array}$ & $\begin{array}{l}\text { Age of last } \\
\text { breeding } \\
\text { (years) (w) }\end{array}$ & $\mathrm{L}_{\max }$ & $\mathrm{r}_{\max }$ \\
\hline Mitu tuberosa & 3.06 & 3 & 1 & 18 & 1.46 & 0.3818 \\
Penelope jacquacu & 1.28 & 3 & 1.1 & 14 & 1.49 & 0.3993 \\
Pipile cumanensis & 1.3 & 3 & 1.3 & 14 & 1.54 & 0.4337 \\
Ortalis guttata & 0.5 & 3 & 2 & 14 & 1.76 & 0.5276 \\
\hline
\end{tabular}

Table 2. Comparison of clutch size of cracids from the literature and from reports by hunters interviewed in a study in the Pacaya-Samiria National Reserve carried out between May 1995 and August 1996

\begin{tabular}{lllll}
\hline & Species & & & \\
\cline { 2 - 5 } Source & Mitu tuberosa & Penelope jacquacu & Pipile cumanensis & Ortalis guttata \\
\hline Literature & 2 & 2.5 & $3-4$ & $2-4$ \\
Hunters & $2 \pm 0(n=36)$ & $2.2 \pm 0.6(n=52)$ & $2.6 \pm 1.3(n=26)$ & $4 \pm 1.3(n=28)$ \\
\hline
\end{tabular}

$n$, number of nests reported by hunters.

Table 3. Population densities of cracids in the three study sites in the Pacaya-Samiria National Reserve from a study carried out between May 1995 and August 1996

\begin{tabular}{|c|c|c|c|c|}
\hline $\begin{array}{l}\text { Sites / } \\
\text { Species }\end{array}$ & $\begin{array}{l}\text { Density } \\
\text { ind./sq km }\end{array}$ & $\begin{array}{l}\% \text { Coefficient } \\
\text { of Variation }\end{array}$ & d.f. & $\begin{array}{l}95 \% \text { Confidence } \\
\text { Interval }\end{array}$ \\
\hline \multicolumn{5}{|c|}{ Fully protected area } \\
\hline \multicolumn{5}{|c|}{ Samiria site } \\
\hline Mitu tuberosa & 1.65 & 24.37 & 20 & $1.00-2.72$ \\
\hline Penelope jacquacu & 5.46 & 25.71 & 22 & $3.23-9.23$ \\
\hline Pipile cumanensis & 6.79 & 33.09 & 11 & $3.34-13.82$ \\
\hline Ortalis guttata & 3.28 & 59.0 & 2 & $0.30-35.08$ \\
\hline \multicolumn{5}{|c|}{ Moderately hunted area } \\
\hline \multicolumn{5}{|c|}{ Yanayacu site } \\
\hline Mitu tuberosa & 2.08 & 50 & 4 & $0.56-7.7$ \\
\hline Penelope jacquacu & 5.46 & 25.71 & 22 & $3.23-9.23$ \\
\hline Pipile cumanensis & 9.37 & 28.87 & 12 & $5.06-17.36$ \\
\hline Ortalis guttata & 3.6 & 54.01 & 3 & $0.73-18.26$ \\
\hline \multicolumn{5}{|c|}{ Heavily hunted area } \\
\hline \multicolumn{5}{|c|}{ El Pinche site } \\
\hline Mitu tuberosa & 0.02 & - & - & $*$ \\
\hline Penelope jacquacu & 0.22 & 70.71 & 2 & $0.14-3.45$ \\
\hline Pipile cumanensis & 0.44 & 40.82 & 6 & $0.17-1.16$ \\
\hline Ortalis guttata & 5.95 & 44.72 & 5 & $1.98-17.84$ \\
\hline
\end{tabular}

\footnotetext{
* Sample size was too small to measure confidence interval.
} 
non-hunted site. In the model, the maximum rate of population increase $\left(\mathrm{L}_{\max }\right)$ was estimated by taking the exponential of $r_{\max }$, which was calculated using Cole's equation (1954).

$$
1=\mathrm{e}^{-\mathbf{r}_{\max }}+\mathrm{be}^{-\mathbf{r}_{\max (a)}}-\mathrm{be} \mathrm{e}^{-\mathbf{r}_{\max }(\mathrm{w}+1)}
$$

Where (a) is the age of first reproduction, (w) is the age of last reproduction, and (b) is the annual birth rate of female offspring (Table 1). The sustainable maximum harvest was assumed to be 20 per cent of $P_{\max }$, which accounts for prereproductive and adult mortality (Slade et al., 1998). Sustainability of the current cracid harvest was assessed by comparing estimates of maximum sustainable harvest with current rates of harvest. We estimated the catchment area by mapping the location of hunting grounds. Because hunters used canoes and limited their hunting activities to $2 \mathrm{~km}$ into the forest from the edge of water courses, we multiplied the length of the rivers and small tributaries by four to obtain the catchment area.

\section{Results}

\section{Breeding biology}

Reproductive biology of the four cracids was determined from 169 nests reported by 53 hunters. Hunters reported a clutch size of $2 \pm 0$ for M.tuberosa, which is the same as previously published reports (Estudillo-Lopez, 1988; Schifter, 1989). However, hunters reported a clutch size of $2.6 \pm 1.3$ for $P$. cumanensis, $2.2 \pm 0.6$ for $P$. jacquacu and $4 \pm 1.3$ for $O$. guttata, which differ from previous reports (Delacour and Amadon, 1973; EstudilloLopez, 1988; Schifter, 1989; Table 2). Nests were found between the months of November and February. Adult birds with fledglings were also seen between November and February $(n=37)$. The peak of singing activity was in November and December. A.J.B. observed a family group of $O$. guttata with fledglings of c. 2 months old in mid-May, which suggests that the breeding season may extend into March. Age of fledglings was estimated by the size and characteristics of plumage relative to adults (Delacour and Amadon, 1973).

\section{Habitat preferences}

Hunters reported that cracids in PacayaSamiria have habitat preferences $(\mathrm{G} 2=146.2$, d.f. $=6, P<0.001$ ). Mitu tuberosa associates more with forests prone to inundation, termed bajial (G2 $=61.73$, d.f. $=1, P<0.001$ ), and to a lesser extent with floodplain levees, termed restingas $(\mathrm{G} 2=4.19, \quad$ d.f. $=1, \quad P=0.034)$. Penelope jacquacu associates more with floodplain levees (G2 $=64.47$, d.f. $=1, P<0.001$ ) and less with forest prone to inundation and other types of forest ( $\mathrm{G} 2=7.64$, d.f. $=1, P=$ 0.006). There was no clear association of $P$. cumanesis and $O$. guttata with any habitat type (G2 $=3.51$, d.f. $=2, P=0.173$ ).

\section{Population density estimates}

Density estimates of Cracidae were higher in the lightly/non-hunted and moderately hunted sites than near the villages (Table 3). In heavily hunted areas at $5 \mathrm{~km}$ from the villages, populations of $M$. tuberosa have been reduced by 98 per cent compared with the lightly/non-hunted site, $P$. jacquacu by 95 per cent and $P$. cumanensis by 94 per cent. Ortalis guttata, the smallest cracid in the region, thrives on forest edges and agricultural areas and because of its small size, is seldom hunted.

\section{Hunting}

Hunting of cracids differed between communities: 71 per cent of cracids taken were hunted in Nueva Esperanza, 21.2 per cent in Maipuco, and 7.6 per cent in San Antonio. The most frequently hunted cracid was $P$. cumanensis, making up 59.1 per cent of the total cracid harvest, followed by $M$. tuberosa comprising 19.7 per cent, $P$. jacquacu making up 16.4 per cent, and O. guttata comprising 4.5 per cent (Table 4).

Cracids represent an important source of meat for people at the three villages. Hunters were estimated to extract $425 \mathrm{~kg}$ of cracid biomass during a year. Indeed, $P$. cumanensis was the most frequently hunted animal in the three communities (Table 5). Hunting trips of local people were usually short trips within $5-7 \mathrm{~km}$ 
Table 4. Ninety-day recorded harvests and estimated annual harvests of cracids in three villages on the edge of the Pacaya-Samiria National Reserve between 11 May and 14 August 1995

\begin{tabular}{llllll}
\hline & \multicolumn{3}{l}{90 -day harvest } & & \\
\cline { 2 - 4 } Species & Maipuco & $\begin{array}{l}\text { Nueva } \\
\text { Esperanza }\end{array}$ & $\begin{array}{l}\text { San } \\
\text { Antonio }\end{array}$ & $\begin{array}{l}\text { All } \\
\text { villages }\end{array}$ & $\begin{array}{l}\text { Estimated } \\
\text { annual harvest }\end{array}$ \\
\hline Mitu tuberosa & 2 & 10 & 1 & 13 & 53 \\
Penelope jacquacu & 2 & 9 & 0 & 11 & 45 \\
Pipile cumanensis & 10 & 25 & 4 & 39 & 158 \\
Ortalis guttata & 0 & 3 & 0 & 3 & 3 \\
Total & 14 & 47 & 5 & 66 & 259 \\
\hline
\end{tabular}

Table 5. Annual cracid and mammalian harvest by no. of individuals hunted and biomass harvested, together with ranked indices, in three villages on the edge of the Pacaya-Samiria National Reserve from studies carried out between 11 May and 14 August 1995 (cracids) and between August 1994 and August 1995 (mammals)*

\begin{tabular}{|c|c|c|c|c|c|}
\hline \multicolumn{2}{|l|}{ Species } & \multirow{2}{*}{$\begin{array}{l}\text { No. } \\
\text { harvested }\end{array}$} & \multirow{2}{*}{$\begin{array}{l}\text { Rank no. } \\
\text { harvested }\end{array}$} & \multirow{2}{*}{$\begin{array}{l}\text { Biomass } \\
\text { harvested } \\
(\mathrm{kg})\end{array}$} & \multirow{2}{*}{$\begin{array}{l}\text { Rank } \\
\text { biomass } \\
\text { harvestec }\end{array}$} \\
\hline Scientific name & English name & & & & \\
\hline Tayassu pecari & White-lipped peccary & 52 & 6 & 1716 & 1 \\
\hline Tapirus terrestris & Lowland tapir & 9 & 17 & 1440 & 2 \\
\hline Agouti paca & Paca & 86 & 4 & 770 & 3 \\
\hline Dasyprocta fuliginosa & Black agouti & 122 & 2 & 610 & 4 \\
\hline Mazama americana & Red brocket deer & 14 & 14 & 445 & 5 \\
\hline Tayassu tajacu & Collared peccary & 18 & 13 & 438 & 6 \\
\hline Hydrochoerus hydrochaeris & Capybara & 29 & 10 & 390 & 7 \\
\hline Cebus apella & Brown capuchin & 97 & 3 & 337 & 8 \\
\hline Alouatta seniculus & Red howler monkey & 34 & 8 & 268 & 9 \\
\hline Pipile cumanensis & Common piping guan & 158 & 1 & 205.4 & 10 \\
\hline Mitu tuberosa & Razor-billed curassow & 53 & 5 & 162.2 & 11 \\
\hline Dasypus novemcinctus & Nine-banded armadillo & 32 & 9 & 160 & 12 \\
\hline Lagothrix lagothrica & Common wolly & 8 & 18 & 121 & 13 \\
\hline Cebus albifrons & White-fronted capuchin & 25 & 11 & 74 & 14 \\
\hline Potos flavus & Kinkajou & 22 & 12 & 65 & 15 \\
\hline Panthera onca & Jaguar & 1 & 22 & 60 & 16 \\
\hline Penelope jacquacu & Spix's guan & 45 & 7 & 57.6 & 17 \\
\hline Ateles paniscus & Black spider monkey & 7 & 19 & 55 & 18 \\
\hline Felis concolor & Puma & 1 & 22 & 45 & 19 \\
\hline Tamandua tetradactyla & Collared anteater & 6 & 20 & 28 & 20 \\
\hline Pithecia mocachus & Monk saki monkey & 10 & 16 & 19 & 21 \\
\hline Bidelphidae & Opossums & 7 & 19 & 11 & 22 \\
\hline Felis pardalis & Ocelot & 1 & 22 & 10 & 23 \\
\hline Bradypus variegatus & Three-toed sloth & 2 & 21 & 8 & 24 \\
\hline Saimiri spp. & Squirrel monkeys & 9 & 17 & 7.2 & 25 \\
\hline Ortalis motmot & Speckled chacalaca & 12 & 15 & 6 & 26 \\
\hline Aotus nancymae & Night monkey & 6 & 20 & 4.8 & 27 \\
\hline Sciurus spp. & Squirrels & 6 & 20 & 4.5 & 28 \\
\hline Saguinus fuscicollis & Saddlebacked tamarin & 1 & 22 & 0.8 & 29 \\
\hline
\end{tabular}

* Data from Bodmer et al., in press. 
Table 6. Estimates of $P_{\max }$ and maximum sustainable harvest levels for cracids in the Pacaya-Samiria National Reserve from a study carried out between May 1995 and August 1996

\begin{tabular}{lllllc}
\hline Species & $\begin{array}{l}\text { Density } \\
\text { ind./sq km }\end{array}$ & $\begin{array}{l}\mathrm{P}_{\max } \\
\text { ind./sq } \mathrm{km}\end{array}$ & $\begin{array}{l}\text { Max. sustainable } \\
\text { annual harvest } \\
\text { ind./sq km }\end{array}$ & $\begin{array}{l}\text { Max. sustainable } \\
\text { annual harvest } \\
\text { ind./276 sq km }\end{array}$ & $\begin{array}{l}\text { Current annual } \\
\text { harvest within the } \\
276 \mathrm{sq} \text { km }\end{array}$ \\
\hline Mitu tuberosa & 1.56 & 0.43 & 0.08 & 23 & 53 \\
Penelope jacquacu & 5.46 & 1.61 & 0.32 & 88 & 45 \\
Pipile cumanensis & 8.08 & 2.62 & 0.52 & 144 & 158 \\
Ortalis guttata & 3.06 & 1.89 & 0.37 & 102 & 3 \\
\hline
\end{tabular}

of the villages, mostly by land, and usually only lasting a day, or long trips covering large distances and large catchment areas along watercourses, which last from several days to entire weeks.

\section{Sustainability of cracid hunting}

Current harvests of $M$. tuberosa and $P$. cumanensis in the 276-sq-km catchment area are not sustainable, because current harvest levels exceed estimated maximum sustainable harvests (Table 6). In contrast, current harvests of $P$. jaquacu and O. guttata are within estimated maximum sustainable levels and therefore might be sustainable.

\section{Discussion}

Cracids are vulnerable to extinction. For example, of the 44 known species of Cracidae (Delacour and Amadon, 1973), 30 per cent are listed in the red data book of Neotropical birds (Collar et al., 1992). Thirty-seven percent of guans and curassows (the largest members of the family) are listed in several categories of threat, which is significantly higher than the 8-10 per cent listing rate for most bird families (Collar et al., 1992). Two species of curassow and four species of guans are listed on Appendix I and populations of four curassows, one chacalaca and two guans on Appendix II of the Convention on International Trade in Endangered Species (IUCN, 1996). Extinction of cracids will be more than species-specific events, because many of them are considered to be ecologically important and their declines will probably have negative impacts on forest structure (Levey, 1994).

Conservation of cracids in Latin America is important but the strategies need to be broadened. We concur that low rates of recovery of cracid populations make it difficult for them to tolerate high levels of continuous hunting (Lovejoy and Brash, 1984; Delacour and Amadon, 1973; Strahl and Grajal, 1991). However, this does not mean that fully protected areas are the only option for cracid conservation in the wild (Delacour and Amadon, 1973; Lovejoy and Brash, 1984; EstudilloLopez, 1988; Stahl and Grajal, 1991). Indeed, fully protected areas only represent a small fraction of cracid habitat.

Conservation of cracids should also focus on the vast areas inhabited by humans and subject to hunting. A critical characteristic of the lowlands of tropical America is that they are largely inhabited by local people (RaezLuna, 1995). Land used by rural Amazonians is estimated to cover $1,727,797 \mathrm{sq} \mathrm{km}$ of rain forest in Peru, Colombia and Brazil. For example, in Peru 1000 Indian communities occupy $736,443 \mathrm{sq} \mathrm{km}$ of Amazonian land, but only $50,000 \mathrm{sq} \mathrm{km}$ are currently protected (Raez-Luna 1995).

This study suggests that the impact of hunting cracids may be minimized if the hunting is in extensive areas, is sporadic, and these hunting areas are surrounded by unhunted populations. Silva and Strahl (1991) have proposed a similar strategy for conserving cracids. Many rural Amazonians use wildlife in a way similar to the hunting described in this study (Alcorn, 1993; Redford and Stearman, 1993). 
Therefore, habitat outside protected areas needs to be managed in a way that combines hunted and non-hunted areas (McCullough, 1996).

Understanding the impact hunters have on cracid populations is critical for managing cracid hunting. In the Pacaya-Samiria National Reserve hunters might be creating sink areas along waterways during longer hunting trips. In turn, cracids may repopulate these sink areas created by hunting. For example, hunters that go on longer hunting trips distribute their hunting activities sparsely in large areas along waterways. If these areas are overhunted, the unhunted populations inland of waterways could be acting as source populations that replenish overhunted areas. The constant flux of individuals from unhunted areas and the sparse nature of hunting in these areas help maintain seemingly stable populations of game animals under harvest pressure (Novaro, 1995). In contrast, areas close to villages have a higher and more constant hunting pressure. This greater intensity of hunting may be too great for cracid populations to sustain, either by reproduction or immigration.

Determining sustainability of cracid harvests relies on many assumptions. Results indicated that current harvests of $P$. jaquacu and O. guttata may be sustainable. However, the Robinson and Redford model does not allow us to determine if these harvests are actually sustainable. Harvests of $M$. tuberosa and $P$. cumanensis were clearly not sustainable.

Body-size differences may explain the greater harvest pressure on $M$. tuberosa, which is the largest cracid in the region. The rate of harvest depends on the frequency of hunter-bird encounters. Hunters often pass smaller-sized birds and pursue the largest cracid upon encounter. A similar pattern has been observed with hunting of mammals in the Peruvian Amazon (Bodmer, 1995).

Conservation of cracids will be enhanced by working with rural Amazonians on converting unmanaged harvests to managed hunting. This in turn will help prevent cracid populations from becoming rare and prone to local extinction. However, studies such as this one on the impact of hunting cracid populations are needed to implement appropriate management. These studies can then help develop management programmes to convert overhunting to more sustainable harvests.

\section{Acknowledgements}

We are indebted to the tremendous support provided by the communities of the Reserva Nacional Pacaya-Samiria who participated in this project; and to Rolando Aquino, Pablo Puertas and César Reyes who helped with the fieldwork. Logistical and financial support were provided by The Biodiversity Support Program, the Chicago Zoological Society, the Wildlife Conservation Society, The Nature Conservancy, the Fundación Peruana para la Conservación de la Naturaleza, University of Florida's Programs for Tropical Conservation, Instituto Nacional de Recursos Naturales - Peru, the Universidad Nacional de la Amazonía Peruana, and the Asociación para la Conservación de la Amazonía.

\section{References}

Alcorn, J. 1993. Indigenous people and conservation. Conservation Biology, 7, 424-426

Ayres, M., Magalhaes-Lima, D., De Sousa Martins, E. and Barreiros, J.L. 1991. On the tract of the road: changes in subsistence hunting in a Brazilian Amazonian village. In Neotropical Wildlife Use and Conservation (eds J. G. Robinson and K.H. Redford), pp. 82-92. University of Chicago Press, Chicago.

Begazo, A.J. 1996. Use de la poblaciones de paujiles, pucacungas, pavas de monte y manajaracos (Cracidae-Galliformes) en el noreste peruano. In Manejo de Fauna Silvestre en la Amazonia (eds T. G. Fang, R. E. Bodmer, R. Aquino and M. Valqui), pp. 257-266. Editorial Instituto de Ecologia, La Paz, Bolivia.

Bodmer, R.E. 1995. Managing Amazonian wildlife: biological correlates of game choice by detribalized hunters. Ecological Applications, 5, 872-877.

Bodmer, R.E., Reyes, C. Allen, C., Penn, J. and Aquino, R. In press. Evaluating the sustainable use of wildlife in the Pacaya-Samiria National Reserve, Peru. America Verde.

Buckland, S.T., Anderson, D, Burnham, K. and Laake, J. 1993. Distance Sampling. Estimating the Abundance of Biological Populations. Chapman and Hall, London.

Cole, L.C. 1954. The population consequences of life history phenomena. Quarterly Review of Biology, 29, $103-137$. 
Collar, N.J., Gonzaga, L., Krabbe, N, Madroño Nieto, A., Naranjo, L., Parker III, T. and Wege, D. 1992. Threatened Birds of the Americas. The ICBP/IUCN Red Data Book. Smithsonian Institution Press, Washington.

Delacour, J. and Amadon, D. 1973. Curassows and Related Allies. The American Museum of Natural History, New York.

Erard, C. and Sabatier, M. 1994. Fruit eating and ornithocory in the forests of Guyana: the example of large terrestrial birds and Marail guan. Alauda, 62 (1), 27-31.

Estudillo-Lopez, J. 1988. Breeding cracids in captivity. Proceedings of World Conference of Breeding of Endangered Species in Captioity, 5, 159-163.

IUCN Species Survival Commission, 1996. IUCN Red List Categories. IUCN, Gland, Switzerland.

Laake, J.L. Buckland, S., Anderson, D. and Burnham, K. 1994. Distance user's guide V2.1. Colorado Cooperative Fish and Wildlife Research Unit. Colorado State University, Fort Collins.

Levey, D. 1994. Cracids as seed dispersers: what we need to know and why this is important. The Cracid Newsletter, 3, 3-4.

Lovejoy, T.E. and Brash, A.R. 1984. Homage au Jean D'arc or the conservation of the Cracidae. Dodo, Journal of Jersey Wildlife Preservation Trust, 21, 33-42.

McCullough, D.R. 1996. Spatially structured populations and harvest theory. Journal of Wildlife Management, 60, 1-9.

Novaro, A. 1995. Sustainable harvest of Culpeo fox in Patagonia. Oryx, 29, 18-22.

Raez-Luna, E.F. 1995. Hunting large primates and conservation of the Neotropical rain forests. Oryx, $29,43-48$.

Redford, K. and Stearman, A. 1993. Forest-dwelling native Amazonians and the conservation of biodiverstiy: interest in common or in collision? Conservation Biology, 7, 248-255.

Robinson, J. and Redford, K. 1991. Sustainable harvest of Neotropical forest mammals. In Neotropical Wildlife Use and Conservation (eds. J. G. Robinson and K. H. Redford), pp. 415-429. University of Chicago Press, Chicago.

Schifter, H. 1989. Early longevity and breeding records of curassows (Cracidae). Rivista Italiana di Ornitologia, 59, 70-74.

Silva, J. and Strahl, S. 1991. Human impact on populations of chachalacas, guans and curassows (Galliformes: Cracidade) in Venezuela. In Neotropical Wildlife Use and Conservation (eds J. G. Robinson and K.H. Redford), pp. 37-52. University of Chicago Press, Chicago.

Slade, N., Gomulkiewicz, R. and Alexander, H. 1998. Alternatives to Robinson and Redford's method of assessing overharvest from incomplete demographic data. Conservation Biology, 12, 148-155.

Strahl, S.D. and Grajal, A. 1991. Conservation of large avian frugivores and the management of Neotropical protected areas. Oryx, 25, 50-55.

Terborgh, J. 1986. Keystone plant resources in the tropical forest. In Conservation Biology (eds M. E. Soule and B. A. Wilcox), pp. 330-344. Sinauer, Sunderland, Massachusetts.

Texeira, D.M. and Snow, D.W. 1982. Notes on the nesting of the red-billed curassow Crax blumembachii. Bulletin of the British Ornithological Club, 102, 83-84.

Thiollay, J.M. 1989. Area requirements for the conservation of rain forest raptors and game birds in French Guiana. Conservation Biology, 3, 128-137.

Vickers, T.W. 1991. Hunting yields and game composition over 10 years in an Amazonian indian territory. In Neotropical Wildlife Use and Conservation (eds. J. G. Robinson and K. H. Redford), pp. 53-81. University of Chicago Press, Chicago.

Alfredo J. Begazo, Department of Wildlife Ecology and Conservation, University of Florida, 303 Newins-Ziegler Hall, Gainesville, FL 32611, USA.

Richard E. Bodmer, Programs in Tropical Conservation, Department of Wildlife Ecology \& Conservation and Center for Latin American Studies, University of Florida, 319 Grinter Hall, Gainesville, FL 32611, USA.

Received 24 January 1997

Accepted 27 May 1998 